\title{
Study on Temperature Control and Crack Prevention of Concrete with Strong Constrained Area in Super-Strong BaseRock
}

\author{
Yang Feng ${ }^{1, a}$,Song Jiadong ${ }^{2, b}$, Wang Wanqin ${ }^{3, c}$, Zhang Jingtao ${ }^{3, d}$, Qiang \\ Sheng ${ }^{3, e}$ \\ ${ }^{1}$ Henan Chushandian Reservoir Construction Administration,China \\ ${ }^{2}$ Henan Hydraulic Engineering First Bureau, China \\ ${ }^{3}$ Hohai University ,China \\ ayangfeng@hnsl.gov.cn, b3263506148@qq.com, c1264084413@qq.com, d1251709535@qq.com, \\ esqiang2118@hhu.edu.cn
}

Key words: concrete dam, strong constraint area, super strong baserock, temperature control and crack prevention

Abstract. The concrete dam of Chushandian reservoir is made of normal concrete, whose strong constraint area of mass concrete cast in the spring is based on granite rock with elastic modulus of 55GPa.The super-strong baserock makes the temperature control and crack prevention of concrete very difficult. Based on hydration degree algorithm, numerical simulation was applied for a typical non-overflow dam section on a strong constraint area during construction and early working period. Concrete temperature field and stress field were obtained under such a special conditions. Then a reasonable quantitative standards of temperature control and cracking prevention were put forward, which may provide some reference to similar projects.

\section{Introduction}

Chushandian reservoir is a large flood-control projects on the Huaihe River, located in xinyang city, Henan province. The dam site is near the Chushandian village of $14 \mathrm{~km}$, west of Beijing-Guangzhou Railway, about $15 \mathrm{~km}$ from xinyang city. The only flood control project in the Huaihe River Basin in the past Huaihe River Basin planning is Chushandian reservoir. It is given priority to with the flood control, combined with water supply, irrigation, both power generation, etc.. The project is composed of multiple dam types. The main dam axis length is $3690.57 \mathrm{~m}$, in which the earth dam length is $3261 \mathrm{~m}$, and concrete dam section length is $429.57 \mathrm{~m}$ (including connecting dam section), with a crest elevation of $100.4 \mathrm{~m}$.

Because the dam is made of normal concrete, which uses the large amount of cementitious material in per unit volume of concrete. The cement used in the non-overflow dam section is nonlow-heat cement and the amout is large, especially the strong constraint area is located on the super strong baserock of 55GPa. Casting temperature and ambient temperature are high in the spring, which makes the mass concrete in the strong constraint area temperature control and crack prevention difficult [1,2].

\section{Calculation Model and the Main Parameters}

The whole finite element model is established for a typical non - overflow dam section. This paper focuses on the dam concrete in the strong constraint area, as shown in figure 2 and figure 3 . The materials in dam upstream is C25 concrete, cover layer and downstream is C20 concrete, dam heart is $\mathrm{C} 15$ concrete.

Boundary conditions: In the temperature field simulation calculation, it is assumed that the bottom and the surrounding of the dam foundation are adiabatic boundary, and the other side is the heat exchange boundary $[3,4]$. In the calculation of the stress field, it is assumed that the bottom of foundation is hinged bearing, surrounded by connecting rod support, the upper structure are free. The first layer and the second layer are made of $\mathrm{C} 20$ concrete, whose casting thickness is $1.5 \mathrm{~m}$, the casting thickness of third layer made of $\mathrm{C} 15$ concrete is $3.0 \mathrm{~m}$. 


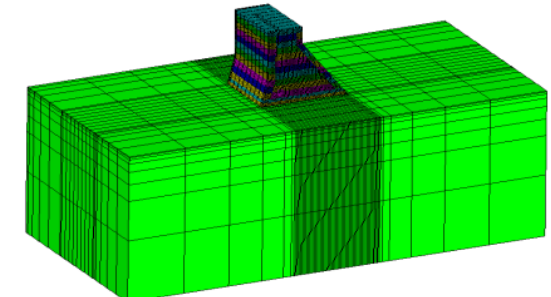

Fig1. Whole model

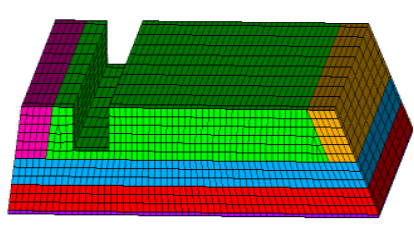

Fig2 .Concret in strong constraint area

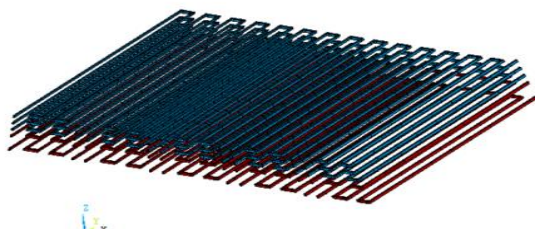

Fig3. Cooling pipes in strong constrained area

The annual average daily temperature variation is calculated as follows:

$$
T_{a}(t)=15.7+13 \times \cos \left[\frac{\pi}{6}(t-6)\right], \quad t \text { for the month }
$$

The main thermodynamic parameters are shown in Table 1.

Table 1 Thermal and mechanical parameters of the materials

\begin{tabular}{|c|c|c|c|c|c|c|c|}
\hline Material & $\begin{array}{l}\text { Thermal } \\
\text { Conductivit } \\
\mathrm{y} \\
\lambda \\
\left(\mathrm{KJ} /\left(\mathrm{m}_{\mathrm{c} . \mathrm{h} .}{ }^{\circ} \mathrm{C}\right)\right)\end{array}$ & $\begin{array}{c}\text { Adiabatic } \\
\text { temperatur } \\
\text { e rise final } \\
\text { value } \\
\theta_{0} \\
\left({ }^{\circ} \mathrm{C}\right)\end{array}$ & $\begin{array}{l}\text { Temperatu } \\
\text { re } \\
\text { conductivi } \\
\text { ty } \\
a\left(\mathrm{~m}^{2} / \mathrm{h}\right)\end{array}$ & $\begin{array}{l}\text { Coefficient } \\
\text { of linear } \\
\text { expansion } \\
\alpha^{\alpha}\left(10^{-6} /{ }^{\circ} \mathrm{C}\right)\end{array}$ & $\begin{array}{l}\text { Poisso } \\
\text { n's } \\
\text { ratio } \mu\end{array}$ & $\begin{array}{l}\text { Dens- } \\
\text { ity } \\
\rho \\
\left(\mathrm{kg} / \mathrm{m}^{3}\right)\end{array}$ & $\begin{array}{c}\text { Final } \\
\text { elastic } \\
\text { modul } \\
\text { us } \\
E_{0} \\
(\mathrm{GPa})\end{array}$ \\
\hline C15 & 9.663 & 34.0 & 0.00445 & 8.363 & 0.167 & 2350 & 28.8 \\
\hline $\mathrm{C} 20$ & 9.613 & 39.5 & 0.00444 & 8.378 & 0.167 & 2353 & 30.3 \\
\hline $\mathrm{C} 25$ & 9.546 & 41.5 & 0.00441 & 8.373 & 0.167 & 2357 & 31.7 \\
\hline $\begin{array}{l}\text { Foundat } \\
\text { ion }\end{array}$ & 10.50 & 0.0 & 0.00548 & 7.00 & 0.20 & 2680 & 55.0 \\
\hline
\end{tabular}

\section{Calculation Results Analysis}

Based on the hydration degree of temperature field and stress field simulation calculation program[5-8], after 23 cases of optimization, the following main conclusions are obtained. Due to space limitations, only the most optimal case results as shown in Figure 4 to Figure 7.

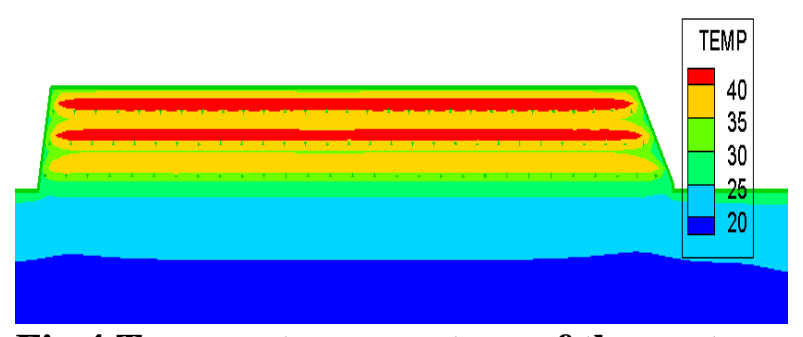

Fig.4 Temperature countour of the center section in the dam strong constraint area

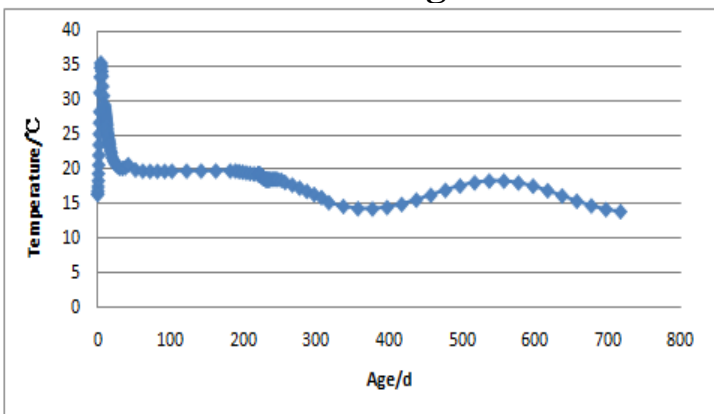

Fig.6 Curve of temperature at midpoint of strong constraining area

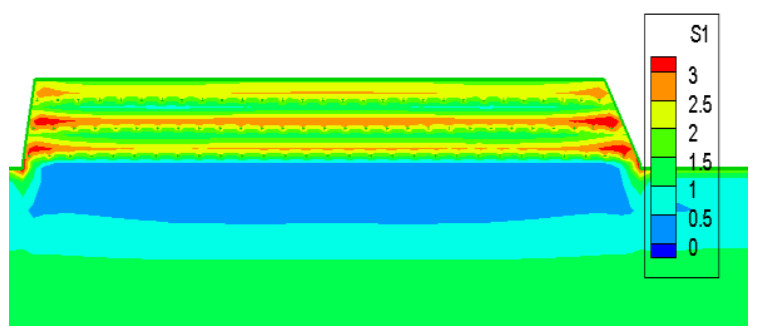

Fig.5 The first priciple stress countour of the center section in the dam strong constraint area

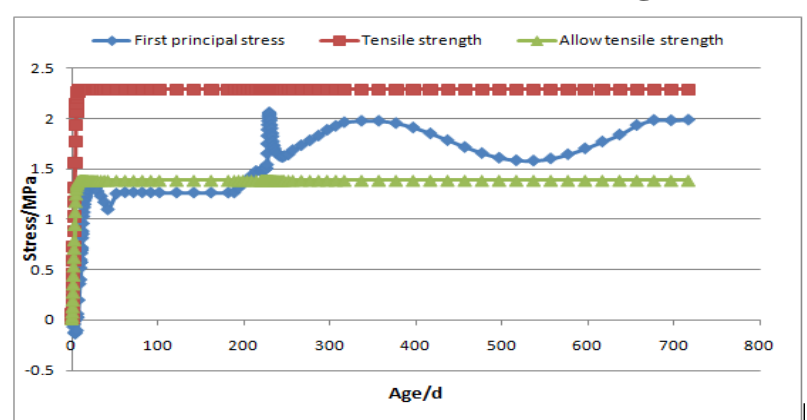

Fig.7 Curve of the first principal stress at midpoint of strong constraining area 
(1) The baserock is granite with elastic modulus of 55GPa, whose strength is very large. It put great pressure on crack prevention for the strong constraint area of the dam. Another disadvantage is the strong constraint area casted in the spring, which make the casting temperature and ambient temperature very high. For the above two reasons, tensile stress generated by the strong constraint area is very large in the autumn and winter. If there is no crack prevention measures, C20 concrete highest temperature is expected to reach $38{ }^{\circ} \mathrm{C} \sim 45{ }^{\circ} \mathrm{C}$ in late March to early April, and the maximum temperature will reach $47^{\circ} \mathrm{C} \sim 50^{\circ} \mathrm{C}$ in mid to late April. When the temperature decreases, shrinkage happens in the concrete. The maximum tensile stress inside the concrete will reach about $4 \mathrm{MPa}$, obviously more than the tensile strength of $\mathrm{C} 20$ concrete. And tensile stress in many areas of concrete is too large, it is supposed that more penetrating cracks or deep cracks will occur in the concrete.

(2) As the temperature rising slowly in the early age and average daily air temperature in spring increasing gradually, the internal and external temperature difference does not lead to excessive surface tensile stress. Therefore, early-age stage concrete surface covered with a layer of geomembrane cloth is enough.

(3) Depending on the pipe layout density comparison calculations (using river water for cooling), when the layout is $1 \mathrm{~m} * 1 \mathrm{~m}$, the temperature peak is cut about $4{ }^{\circ} \mathrm{C} .1 \mathrm{~m} * 0.5 \mathrm{~m}$ layout is cut about $6{ }^{\circ} \mathrm{C} .0 .5 \mathrm{~m} * 0.5 \mathrm{~m}$ layout is cut about $10{ }^{\circ} \mathrm{C}$. When the peak temperature decreases, the tensile stress peak value in the internal point of the first layer would decrease. But the maximum tensile stress on the $55 \mathrm{GPa}$ baserock can not be reduced to its tensile strength range if the water pipe cooling is the only measure used in the project.

(4) After pipe cooling + expansion agent were used, it is found that when the autogenous volume shrinkage deformation of the 60 microstrain was reduced to 6 microstrain, equivalent to reducing temperature about $6 \sim 7^{\circ} \mathrm{C}$, crack would not happen.

(5) Trying the water pipe cooling + reducing the $31 \mathrm{~m}$ long edge size to about $15 \mathrm{~m}$, the maximum tensile stress in the first layer would become $2.1 \mathrm{MPa}$, which was under the tensile strength.

(6) Before the flood season, the internal temperature of the concrete is reduced to within $20{ }^{\circ} \mathrm{C}$ (with water pipe cooling), then the possibility of cracking in the strong restraint area during the flood period (water temperature $20^{\circ} \mathrm{C}$ ) is small.

(7) Casting temperature in the calculation shows that if it exceeds $20{ }^{\circ} \mathrm{C}$, whatever measures can not make the tensile stress of concrete in the fall and winter lower than its tensile strength.

\section{Recommended Temperature Control Indicators}

(1) Casting temperature: No more than $20^{\circ} \mathrm{C}$. If it is higher than $20^{\circ} \mathrm{C}$, should not be casted.

(2) Maximum temperature in the concrete: The length of the casting block is needed to reduce. When the longest side of the casting block is not greater than $25 \mathrm{~m}$, the maximum temperature can not be higher than $35^{\circ} \mathrm{C}$. When the longest side of the cast block is no more than $15 \mathrm{~m}$, the maximum temperature can not be higher than $40^{\circ} \mathrm{C}$.

(3) Concrete temperature drop rate: No more than $2{ }^{\circ} \mathrm{C} / \mathrm{d}$.

(4) Internal and external temperature difference: No more than $25^{\circ} \mathrm{C}$ (the difference between the maximum temperature inside concrete and the minimum environmental temperature ).

\section{Conclusion}

Compared with the ordinary concrete dam, there are two great difficulties in mass concrete temperature control and crack prevention work in the strong constraint area. First, the baserock elastic module is very large, reaching 55GPa. The second is the spring casting makes casting temperature and hydration heat temperature peak difficult to control.

The concrete temperature field and stress field in the strong constraint area shows that strict temperature control measures and temperature control index should be adopted to control the internal temperature peak. It will avoid cracks during the flood time,especially in autumn and winter. 


\section{Acknowledgements}

This work was financially supported by the Henan Hydraulic Science and Technology Key Problem Project Foundation, National Natural Science Foundation of China (51679074).

\section{References}

[1] S.K.Chen, Y.M.Zhu, L.Guo: Water Resources and Hydropower. Vol. 27, No.4(2007), p. 114

[2] P.Xu, Y.M.Zhu, N.H.Ben: Water Resources and Hydropower Engineering. Vol.39, No.2(2008), p. 22

[3] S.W.Ji, Y.M.Zhu, P.Xu, L.Guo: Journal of China Three Gorges University(Natural Sciences). Vol. 30,No.2(2008), p.12

[4] J.Q.Deng, Y.M.Zhu: Journal of China Three Gorges University(Natural Sciences). Vol.30,No.5(2008), p.8

[5] Z.Y.Zhu, S.Qiang, W.M.Chen: Journal of Wuhan University of Technology (Materials Science Edition). Vol. 29, No.3(2014), p.540.

[6] M.Cervera, J.Faria, J.Oliver, et al.: Computers \& Structures . Vol.80(2002), p. 1511

[7] G. De.Schutter: Computers \& Structures . Vol.80(2002), p .2035

[8] J.H.Hatte, J.Thorborg: Applied Mathematical Modelling. Vol.27(2003), p. 1 